\title{
放牧牛におけるTrypanosoma theileriの感染状況調查
}

\author{
石田秀史 ${ }^{1 \dagger} \quad$ 太田洋一 ${ }^{2)}$ 仲山美樹子 ${ }^{2)} \quad$ 小見 $\quad$ 清 $^{2)}$

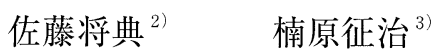 \\ 1）新潟大学大学院自然科学研究科（T 950-2181 新潟市五十嵐二の町 8050) \\ 2) 新潟県下越家畜保健衛生所（干 957-0215 新発田市東新町 1-7-6) \\ 3）新潟大学農学部（† 950-2181 新潟市五十嵐二の町 8050）
}

(2001 年 6 月 18 日受付 $\cdot 2001$ 年 9 月 10 日受理)

要約

放牧牛の Trypanosoma theileri の感染状況を把握する目的で, 放牧牛 24 頭を対象に入牧前から下牧まで毎月 1 回採 血を行い，バフィーコートの培養によるT. theileriの検出㧍よび間接蛍光抗体法による抗体検査を実施した。その結 果，培盖法では入牧前に 24 頭中 3 頭 $(12.5 \%)$ から検出された，入牧後は，夏期に向かって検出率が上昇し 9 月に 24 頭中 14 頭（58.3\%）となった。 その後，検出率は低下した．間接蛍光抗体法による抗体検查では，全調查期間の抗体 価は40〜2,560 倍の範囲に分布し，T. theileriが検出された個体では，80〜1,280 倍の範囲に分布した。また，抗体価 の幾何平均值は, 夏期に向かって上昇する傾向にあり，9月に最高値 640.0 倍を示した.

——ーワード: バフィーコート, 牛, 間接蛍光抗体法, 放牧場, Trypanosoma theileri.

日獣会誌 $55,13 \sim 16 （ 2002 ）$

Trypanosoma theileri は全世界に分布し，わが国に おいても確認されている $[2,4,8]$. しかし，わが国にお ける感染状況については 40 年以上調查がなされておら ず，現時点でのその実態は不明である。そここで，放牧場 における感染状況を明らかにする目的で，新潟県内の 1 放牧場の放牧牛 24 頭を対象として定期的にバフィーコ 一トの培養によるT. theileriの検出および間接蛍光抗体 法による抗体検查を実施した。

\section{材料抒よび方法}

放牧場：新潟県の北部山間地に位置する W 放牧場. 標高 $350 \sim 450 \mathrm{~m}$, 総面積 $36.9 \mathrm{ha}$.

対象牛：3市村 11 戸の農場から集められた前年放牧 牛 5 頭を含む黒毛和種繁殖牛 24 頭（経産牛 14 頭, 未経 産牛 10 頭)。放牧期間は平成 11 年 5 月 7 日 11 月 5 日 までの 182 日間. また, ピロプラズマ病対策のため, 放 牧期間中 2 週間ごとにフルメトリン製剂をプアオン法で 投与した.

検查方法：入牧前の 4 月および入牧後の $6 \sim 11$ 月ま での毎月 1 回, 䫇静脈または尾静脈から EDTA- $\mathrm{Na}$ 添加 および血清分離用真空採血管を用いて採血した．血清は 遠心分離後, 測定時までー $40{ }^{\circ} \mathrm{C}$ で保存した.

血液検査は, 自動血球計算機 クヘマトクリット (Ht) 值および血漿総蛋白量を測定し
た。また，血液塗抹標本を作製後ギムザ染色を施し $T$. theileri 执よびTheileria orientalis 感染の有無を光学顕 微鏡で観察した。

バフィーコート培養による T. theileri の検出：バフィ ーコートの培養は, Schlafer [10］の方法に準じて行っ た.すなわち，12 ウェルマルチプレートの各ウェルに $1 \mathrm{~m} l$ ずつ $10 \%$ 牛胎子血清加イーグル MEM $(50 \mu \mathrm{g} / \mathrm{m} l$ ゲンタマイシンおよび $7 \%$ 炭酸水素ナトリウム水溶液 $2 \%$ 添加）を分注した。次に, 供試EDTA 添加血液を $700 \times \mathrm{g}, 10$ 分間遠心，バフィーコート $50 \mu l /$ 検体を採 取し, マルチプレートの各ウェルに接種後，5\%炭酸ガ 久存在下 $37^{\circ} \mathrm{C}$ で培養した。培養 2 日目または 3 日目， 6 日目または 7 日目および 10 日目に倒立顕微鏡 $(\times 200)$ で観察し，T. theileriに特徽的な波動運動する原虫がみ られた検体をT. theileri 陽性とした。

間接蛍光抗体法による抗体検査: 間接蛍光抗体法は, Reiterら [7］の方法を96ウェルマイクロプレートに応 用した。すなわち，別の放牧場の牛血液から前述の培養 条件下で分離したT, theileriを継代用の培地（8\%めん 羊血液寒天培地 $5 \mathrm{~m} l$ を $50 \mathrm{~m} l$ プラスチックボトル内で凝 固させ, リン酸緩衝生理食塩液（PBS） $2 \mathrm{~m} l$ 加えた培 地）で7日間隔 5 代継代した. 次に, PBS で 3 回洗浄し,

a) Celltac, 日本光電, 東京.

\footnotetext{
$\dagger$ 連絡責任者：石田秀史（新潟県中央家畜保健衛生所） 干 959-0432 新潟県西蒲原郡西川町旗屋 686
} 
放牧牛におけるTrypanosoma theileri の感染状況調査

表 1 放 牧牛 24 頭 の血液検査成績

\begin{tabular}{|c|c|c|c|c|c|c|c|c|}
\hline \multirow{2}{*}{ 区 } & \multirow{2}{*}{ 分 } & \multicolumn{3}{|r|}{ 検 } & 月 & \multicolumn{2}{|l|}{ 日* $^{*}$} & \multirow[b]{2}{*}{ 11. 5} \\
\hline & & 4. 12 & 6.7 & 7. 5 & 8. 6 & 9. 3 & 10. 1 & \\
\hline \multirow[t]{2}{*}{$\mathrm{Ht}(\%)$} & 体 & $39.7 \pm 5.0^{* *}$ & $36.2 \pm 4.8$ & $35.4 \pm 3.6$ & $32.6 \pm 3.3$ & $33.8 \pm 5.1$ & $36.6 \pm 2.6$ & $35.3 \pm 3.0$ \\
\hline & 検出個体 & $40.7 \pm 3.1$ & $36.5 \pm 4.1$ & $37.0 \pm 3.0$ & $35.3 \pm 3.4$ & $37.2 \pm 2.7$ & $38.3 \pm 3.9$ & 38.0 \\
\hline \multirow{2}{*}{$\mathrm{WBC}(\times 100$ 個 $/ \mu l)$} & 全＼cjkstart体 & $69.0 \pm 23.1$ & $75.0 \pm 19.2$ & $84.4 \pm 16.2$ & $84.6 \pm 30.0$ & $76.5 \pm 23.2$ & $67.1 \pm 12.1$ & $69.1 \pm 16.7$ \\
\hline & 検出個体 & $76.3 \pm 13.3$ & $81.5 \pm 10.7$ & $85.7 \pm 14.6$ & $79.5 \pm 20.6$ & $91.7 \pm 28.1$ & $73.3 \pm 14.8$ & 68.0 \\
\hline \multirow[t]{2}{*}{$\mathrm{TP}(\mathrm{g} / \mathrm{d} l)$} & 全 体 & $7.0 \pm 0.7$ & $7.0 \pm 0.5$ & $7.1 \pm 0.5$ & $7.4 \pm 0.5$ & $7.8 \pm 0.4$ & $7.5 \pm 0.4$ & $7.6 \pm 0.4$ \\
\hline & 検出個体 & $6.3 \pm 0.2$ & $7.1 \pm 0.7$ & $7.1 \pm 0.7$ & $7.5 \pm 0.8$ & $7.5 \pm 0.4$ & $7.9 \pm 0.5$ & 7.5 \\
\hline
\end{tabular}

$\mathrm{Ht}$ ：ヘマトクリット值, $\mathrm{WBC}$ : 白血球数, TP : 血漿総蛋白量.

*:4 月は入牧前; $6 \sim 11$ 月は入牧後.

$* *$ : 平均値 \pm 標準偏差.

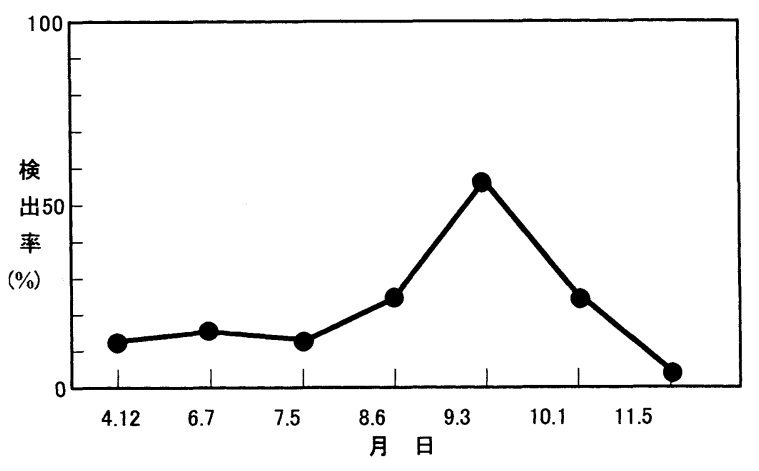

図 1 バフィーコート培養法によるTrypanosoma theileri の検出

$1.25 \times 10^{6} / \mathrm{m} l$ になるようPBSに再浮遊させ， $40 \mu l$ ず つ96ウェルマイクロプレートの各ウェルに分注した. $37{ }^{\circ} \mathrm{C}$ の孵卵器内で 1 夜乾燥させた後, $20 \%$ （v/v）アセ トン加エタノールを $100 \mu \mathrm{l} /$ ウェル加え 10 分間固定し た. 固定後PBSで 3 回洗浄し, 使用まで- $40{ }^{\circ} \mathrm{C}$ に保存 した. 使用時PBSで 1 回洗浄した後, 2 倍階段希釈 （1：20〜 1：2,560）した血清を $50 \mu l /$ ウェル加え $37{ }^{\circ} \mathrm{C} 1$ 時間反応させ, PBSで 3 回洗浄した。次にFITC 標識抗牛 $\operatorname{IgG}$ ウサギ抗体を $50 \mu l /$ ウェル加え $37^{\circ} \mathrm{C} 1$ 時 間反応させた後, PBS で 3 回洗浄し蛍光顕微鏡 $(\times 200)$ で観察した. 特異蛍光が認められた最高希釈倍数の逆数 を抗体価とした。

$$
\text { 成績 }
$$

血液検査成績：血液検査成績を表 1 に示した. 血液塗 抹標本の観察では, 期間中いずれの個体からも T. theileriおよびT. orientalis は検出されなかった. 白血球数 は，3,800〜 17,400 個/ $\mu l$ の範囲に分布し，培養により T. theileriが検出された個体とされなかった個体間での 数值に統計学的に有意差は認められなかった. $\mathrm{Ht}$ 值は $24 \sim 49 \% の$ 範囲に分布, 血漿総蛋白量は $6.0 \sim 8.8 \mathrm{~g} / \mathrm{d} l$ の範囲に分布し, いずれも培養でT. theileri 陽性/陰性 群間で統計学的に有意差は認められなかった.

バフィーコート培養法によるT. theileriの検出：バフ

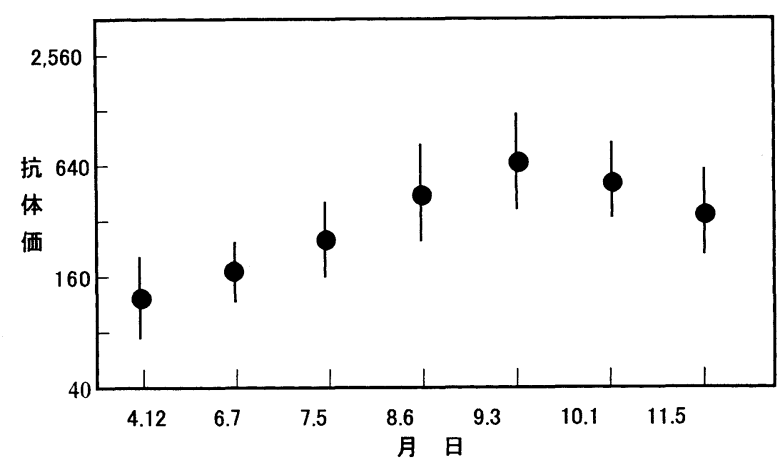

図2 間接蛍光抗体法による抗体価の推移

イーコート培養法によるT. theileri の検出率の推移を図 1 に示した. T. theileri は, 全期間で延べ 37 頭から検出 された。入牧前の 4 月の検査では 24 頭中 3 頭 $(12.5 \%)$ から検出され, 3 頭のうち 2 頭は経産牛で, うち 1 頭は 前年放牧経験牛, 他の 1 頭は放牧経験のない未経産牛で あった，入牧 1 力月後の 6 月は 4 頭 $(16.7 \%)$ から検出 され，8月以降検出率は上昇する傾向がみられ，9月に は半数以上の 14 頭 $(58.3 \%)$ となった. 10 月以降検出 率は低下し，下牧時の 11 月には 1 頭 $(4.2 \%)$ のみの検 出であった。この間 1 回だけ検出された個体は 4 頭で, いずれも 9 月検査であった. 2 回検出されたものは 5 頭, 3 回検出されたものは 3 頭, 4 回検出されたものは 2 頭, 5 回以上検出されたものは 1 頭であった.

抗体検査成績 : 間接蛍光抗体法による抗体価の平均值 の推移を図 2 に示した。各個体の抗体価は，40～2,560 倍の範囲に分布し, 入牧前の 4 月では, 抗体価の平均値 は119.9 倍で期間中最も低い值を示した。また，6月以 降は抗体価の平均值は上昇する傾向にあり，9月が最も 高い 640.0 倍を示し, その後 10 月, 11 月と抗体価は低 下し，11月は369.7 倍であった.

全期間を通じて，T. theileriが分離された個体の抗体 価は, 80 〜 1,280 倍, 分離されなかった個体は 40 2,560 倍であり, 抗体価の平均值で比較した場合, 両者 間に統計学的に有意差は認められなかった. 
仲山美樹子 他

考察

今回の成績では, 入牧前から下牧までの T. theileriの 検出率は，4.2〜 58.3\%で，冬と夏で比較したGlaser [1] の報告（冬期 0\%，夏期 46.7\%）およびNiak [6] の報告（12.5\%と $37.5 \%)$ と同様に夏期検出率が高い 傾向にあった. Schlafer [10］のバフィーコート0.3〜 $0.8 \mathrm{~m} l$ を培養液 $5 \mathrm{~m} l$ に接種した 5 月と 9 月の検出率を比 較した成績では，0\%と66.7\%を示した。今回，原虫検 出に用いたバフィーコート $50 \mu l$ を培養液 $1 \mathrm{~m} l$ に接種し た成績でもほぼ同等の検出率が得られたことから, 本法 のようなより少量の血液材料, 培養液容量でも効率よく T. theileriが検出できるとものと考えられた.

調查期間中の T. theileri の感染は, 吸血昆虫の発生が ないと考えられる4月にすでに 3 頭に認められた。うち 1 頭は前年放牧牛で, 他の 2 頭は放牧経験のない個体で あり, 放牧時以外の畜舎内での吸血昆虫による感染また は垂直感染 [3] が疑われた。これら4月にT. theileri が検出された 3 頭は，いずれも $4 \sim 6$ 月の抗体検査でも， 抗体価に変動がなく, さらに調査期間中 $2 \sim 6$ 回 $T$. theileriが検出されている.このことから，これらの個 体は, 持続感染していたものと考えられ, 他の個体への 感染源となった可能性もある. また, 吸血昆虫の発生が 比較的少ない 6 月の検査では, さらに他の 2 頭からも検 出されたが，1頭ではその後抗体価の上昇がみられ, 新 たな感染を受けた可能性が示唆された. 吸血昆虫の発生 がピークとなる8〜9月に検出率が上昇するとともに, 抗体価も上昇し, さらに吸血昆虫の発生が減少する 10 月以降は，検出率が低下し，抗体価も低下傾向を示し た.このことより夏季に新たな感染が起こったものと推 測された．県内の他の放牧場で $1992 \sim 1994$ 年に行われ た吸血昆虫の発生消長調査 (未発表) および早川（私信） によると, 7 〜月がアブの発生数の最も多い時期とさ れる. 特に本放牧場での 8 月の検査時に観察された飛来 の多いアカウシアブ (Tabanus chrysurus) およびシロ フアブ (Tabanus trigeminus) がT. theileriの媒介に 関与しているものと考えられた. また，9月に原虫が検 出されなかった個体においても 4 月の抗体価と比べると 明らかな抗体上昇が認められ，これらの個体もすべて感 染したものと判断された. しかも, T. theileriが検出さ れた個体よりも高い抗体価を示す個体も認められ, 感染 後の速やかな抗体上昇により血中から原虫が消失したも のと推測される.
一方, T. theileriが検出された 15 頭中 11 頭が 2 回以 上検出され，そのほとんどが連続した 2 回以上の検査で 検出された．．．ｒｒｃeiでは原虫が牛体内で抗原変異を 起こすことが知られており [11], 今回の場合も, $T$. theileriが体内で抗原変異を起こしながら持続感染して いた可能性が考えられたが, IFAによる抗体検查結果か らは，再感染も否定できなく判断できなかった。また， 血液塗抹標本の鏡検では, いずれの検体からも原虫は検 出されなかったことから, 通常牛体内で増殖した場合で も, 血液中に多数出現する期間が短く, その後は, 少数 の出現を繰り返しているのではないかと思われた。

血液検査成績では，バフィーコート培養法により多く の個体から原虫が検出されたが, 貧血などT. theileriの 感染による特徵的な臨床症状を示す個体は認められなか った.また，T. orientalisの寄生も認められなかったこ とから, 複合的な増悪因子が少なく発病に至らなかった ものと考えられた。

今回, 放牧場で同一個体を追跡して T. theileri の検出 を行った結果, 夏期に $58.3 \%$ と高率に検出され, 放牧 場では容易に感染が広がっているものと考えられた．本 原虫の病原性は低いとされているものの, 貧血, 流産等 に関与したことが報告されている $[2,4,5,12]$.また， アブだけでなくダニによる媒介も報告されていることか ら [9], 今後も放牧衛生の中で感染動向を把握していく 必要があると思われる。

\section{引用文 献}

[1] Glaser RW : J Parasitol, 8, 136-148 (1922)

[2] Herbert IV : Vet Bull, 34, 563-570 (1964)

[3] Hussain K, Broidie B, Ott RS, Montealegre F : Am J Vet Res, 46, 1256-1258 (1985)

[4] 岩田明敏, 高村 礼, 喜多英治, 乾 純夫, 川島秀雄, 永井 仁：日獣会誌，12，22-27（1959）

[5] Levine ND, Watrach AM, Kantor S, Hardenbrook HJ : J Parasitol, 42, 533 (1956)

[6] Niak A : Trop Anim H1th, 10, 26-27 (1978)

[7] Reiter I, Buttner M, Seitz A : J Vet Med, B34, 380390 (1987)

[8] 佐々木 昇：日獣会誌, 11, 327-329（1958）

[9 ] Shastri UV, Deshpande PD : Vet Parasitol, 9, 151-155 (1981)

[10] Schlafer DH : Cornell Vet, 69, 411-425 (1979)

[11] Vickerman K : Parasitology, 99, 37-47 (1989)

[12] Ward WH, Hill MWM, Mazlin ID, Foster CK : Aust Vet J, 61, 324 (1984) 
Seasonal Changes in Trypanosoma theileri Infection in Grazing Cattle Hideshi ISHIDA* ${ }^{* \dagger}$, Yoichi OTA, Mikiko NAKAYAMA, Kiyoshi KOMI, Masanori SATO and Seiji KUSUHARA

* Graduate School of Science and Technology, Niigata University, 8050 Igarashi-ninocho,

Niigata 950-2181, Japan

\section{SUMMARY}

Seasonal changes in Trypanosoma theileri infection in grazing cattle (Japanese Black) were investigated by means of buffy-coat culture and indirect fluorescent antibody tests (IFT). Blood samples were collected from 24 cows every month from April to September. T. theileri was detected in 3 out of 24 (12.5\%) of the samples collected before grazing in April. After the animals were put out to graze in a pasture, the detection rate of $T$. theileri increased toward the summer; and in September 14 out of 24 (58.3\%) animals were positive. Throughout the investigation, the overall antibody titer was distributed in the range between $1: 40$ and $1: 2$, 560. The antibody titer in infected cows, however, ranged from $1: 80$ to $1: 1,280$. Geometrical antibody-titer means increased toward summer, to reach a maximum of $1: 640.0$ in September.

- Key words : buffy coat, cattle, indirect fluorescent antibody test, pasture, Trypanosoma theileri.

$\dagger$ Correspondence to : Hideshi ISHIDA (Chuo Livestock Hygiene Service Center, Niigata Prefecture) 686 Hataya, Nishikawa-machi, Nishikanbara, Niigata Prefecuture 949-0423, Japan TEL 0256-88-3141 FAX 0256-88-3185

\section{共済薬価基準表 収載品}
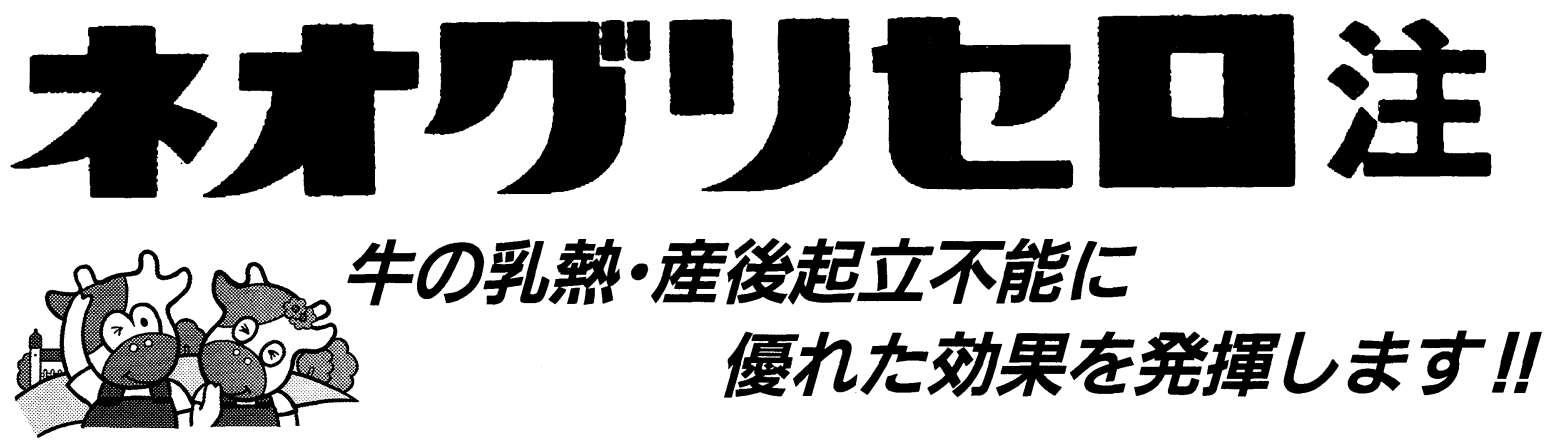

成 分 分 量

(100ml中) グリセロリン酸カルシウム………....7g チアミンジスルフィド硝酸塩………0.2g

効能効果 うし：低カルシウム血症及び低リン血症

\section{お問い合せ TEL. 048-224-8454}

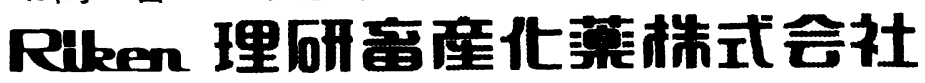

于332-0011 埼玉県川口市元很4-1-8 TEL. 048-224-8451 FAX. 048-224-1079

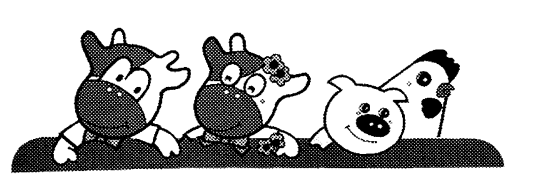

